\title{
Indirect Impact of Covid-19 Lockdown On Society And Environment
}

\author{
Radha Andhare', Yogita Shrivas ${ }^{2}$, Shubhada Guru ${ }^{3}$, Abhishek Joshi ${ }^{4}$ \\ ${ }^{1}$ Professor and HOD, Department of Kriya Sharir, ${ }^{2}$ Professor and HOD, Department of Kaumarbhrutya, \\ ${ }^{3}$ Associate Professor, Department of Kriya Sharir, Datta Maghe Ayurvedic medical College, Hospital and Research \\ centre, Nagpur, ${ }^{4}$ Associate Professor Dept. of Community Medicine, Jawaharlal Nehru Medical College, Datta \\ Meghe Institute of Medical Sciences, Sawangi Meghe, Wardha-442001
}

\begin{abstract}
In a fairly short time, the worldwide spread of COVID-19 has brought a dramatic reduction in industrial activities, road traffic and tourism. During this time of crisis restrained human interaction with nature has appeared as a blessing for nature and the environment. Reports from around the world indicate that environmental conditions, including air quality and water quality in rivers, are improving after the COVID-19 outbreak, and wildlife is blooming. India has always been a pollution hub with enormous populations. But since COVID-19 announced the lockdown, air quality has begun to improve and all other environmental parameters such as water quality in rivers have begun to offer a positive sign of restoration.
\end{abstract}

Keywords: COVID-19, Lockdown, Impact, society, Environment, Trade, Unemployment.

\section{Introduction}

As of 21 August 2020, Covid-19, who emerged in Wuhan somewhere back eight months in December 19, has now taken shelter in host bodies in 213 countries across the globe infecting 22,589,017 people and 792,475 deaths. India has also reported more than 2,905,823 positive cases with 54,849 death tolls on the same day ${ }^{1}$. The disease remains uncontrolled, and the virus has no proven cure. Locking in homes and social distances is the only preventive step the country as a whole is taking. But as the human activities in most areas are limited, the country's natural environment has begun to heal itself. Factories, trade, aircraft and aviation are all at a standstill. Social media has immerged out as platform

\section{Corresponding Author:}

\section{Dr. Radha Andhare}

Professor and HOD, Department of Kriya Sharir, Datta Maghe Ayurvedic medical College, Hospital and Research centre, Nagpur Mob No.: 9359029449, 7709046635

e-mail: rr.khisty@gmail.com for people to stay connected with each other. Lockdown due to COVID-19 has also affected employment status of whole world. Worldwide import and export has been reduced substantially.

\section{Aims and Objectives:}

1. Discussion about the various effects of lockdown due to COVID-19 on environment, mental health, trade, unemployment etc.

2. Try to find solutions on adverse effects.

3. Try to find out solutions to maintain positive effects of lockdown.

\section{Materials and Method}

Material and data for this article is collected from authentic official websites and news channel reports from national and international platform.

\section{Result}

Due to lockdown, environment and society is influenced as follows:

Air Quality: Thanks to the effect on travel and industry of the coronavirus outbreak many regions 
and the world as a whole witnessed a decrease in air pollution. ${ }^{2}$ The Energy and Clean Air Research Centre estimated that strategies for suppressing coronavirus spread, such as quarantines and travel bans, resulted in a $25 \%$ reduction in carbon emissions. ${ }^{3}$ NASA uses an instrument for ozone monitoring (OMI) to measure and monitor the ozone layer and contaminants such as NO2, aerosols and others. According to scientists at NASA, the decline in NO2 emissions originated in Wuhan, China and spread gradually to the rest of the planet. ${ }^{4}$

Water Quality: Water in the canals in Venice cleared and saw greater flow of water ${ }^{5}$. The increase in water clarity was attributed to the settling of sediment which is disturbed by boat traffic and the decrease in air pollution along the waterways listed. ${ }^{6}$

Wildlife: Some animals have been seen in towns as people remain at home due to lockdown and travel restrictions. Sea turtles were seen laying eggs on the beaches they once avoided (such as the Bay of Bengal coast), due to lower human intrusion and light pollution rates. $^{7}$

German scientist Rainer Froese has said that fish biomass will increase due to the sharp decline in fishing, and has projected that some fish such as herring could double their biomass in European waters. ${ }^{8}$

Carbon emission: A study published in May 2020 found that the daily global carbon emissions declined by 17 percent during the lockdown steps in early April and could lead to an annual decrease in carbon emissions of up to 7 percent, which according to researchers would be the largest drop since World War II. They attribute these declines largely to reducing the usage of transport and manufacturing activities. ${ }^{9}$

Public mobility: Public mobility has deteriorated dramatically due to constraints, including the imposition of a lockout in several countries, a Google Study reveals. Across India, shopping and leisure places saw the steepest decline across people's presence between February 16 and March 29 relative to traffic between January 3 and February 6. There was a significant rise in phone traffic from homes, meaning more people were staying at home. Visits to restaurants, shopping malls and movie theatres plummeted by 77 per cent between Feb. 16 and Mar. 29 compared to the period from Jan. 3 to Feb. 6. Visits to stores, markets and pharmacies have dropped by $65 \%$. Visits to national parks, beaches and public gardens have been reduced by $57 \%$. Compared to the period between Jan. 3 and Feb. 6, the use of public transport facilities such as buses and trains fell 71 per cent between Feb. 16 and Mar. 29. Workplace visits declined 47 per cent as many people were told to work from home. People stayed 22 per cent more at home than they did between January 3 and February $6 .{ }^{10}$

Impact on trade: Trade in United States has been declined which shows impact on the trade in other countries of world.

Table: Effect of lockdown on Trade

\begin{tabular}{|c|c|c|}
\hline Sr. & Trade & Export \\
\hline 1 & $\begin{array}{l}\text { Passenger cars and light } \\
\text { trucks }\end{array}$ & $\begin{array}{c}\text { Decreased by } \\
98 \text { percent }\end{array}$ \\
\hline 2 & Engine and parts & Decreased 28.9 \\
\hline 3 & Crude oil & $\begin{array}{c}\text { percent } \\
\text { Decreased } 7.9 \\
\text { percent }\end{array}$ \\
\hline 4 & $\begin{array}{l}\text { Refined petroleum } \\
\text { products }\end{array}$ & $\begin{array}{c}\text { decreased } 9.8 \\
\text { percent }\end{array}$ \\
\hline 5 & Medical equipment & Increased 24.2 \\
\hline 6 & $\begin{array}{l}\text { Medical diagnostic } \\
\text { equipment }\end{array}$ & $\begin{array}{c}\text { Increased } 34.8 \\
\text { percent }\end{array}$ \\
\hline 7 & $\begin{array}{l}\text { Medical diagnostic } \\
\text { products }\end{array}$ & 0 \\
\hline 8 & $\begin{array}{l}\text { Disinfectants and } \\
\text { sterilization products }\end{array}$ & $\begin{array}{l}\text { Increased by } \\
14.4 \text { percent }\end{array}$ \\
\hline
\end{tabular}

Impact on Unemployment: The International Labour Organization (ILO) projected that the spread of corona virus would threaten more than 25 million jobs globally. Four out of five people ( 81 per cent) in the 3.3 billion global work forces are currently impacted by the complete or partial closure of the workplace. The United States, the United Kingdom, Canada and most European and Asian countries have already registered huge jobs losses leading to significant increase in unemployment. The ILO in its report ", describes COVID-19 as 'worst global crisis since World War II ${ }^{11}$.

Low-paid and low-skilled informal workers are particularly concerned in low- and middle-income countries, where the industries and services have a high proportion of these informal employees, who account for 61 per cent of the global workforce or 2 billion men, and lack any social security. The sudden loss of livelihood will make them horrifying.

The CMIE (Centre for Monitoring Indian Economy) report showed a major job loss and corresponding substantial unemployment rate rise in March 2020. The 
unemployment rate in March 2020 stands at 8.7 per cent, which is far higher than the government's estimate of unemployment in 2017-18 at a 45-year high of 6.1 per cent. This is the highest jobless rate since September 2016. Over the same time, the unemployed have also risen from 32 million to 38 million. The situation got worse when we went into the lockdown time last May week and the unemployment rate rose to $23.48 \%{ }^{11}$

Role of Social media during lockdown: During the lockout the social media plays a significant role. During the lockdown social media always update people's current affairs. The role of social media is very important in managing the anger, tension, and fear of the people and in helping they update the current scenario. Also Study indicates that active use of social media is better for you than passive use, so consider writing a blog or sharing status updates as a way to connect. And it will help you organize virtual encounters with family and friends. These should not limit themselves to chatting; they will engage in community activities such as watching films, playing drama and online conversation through video calls and share their views on academic aspects and other aspects of cooking together. Teachers are conducting online lectures for their students so they do not skip their academics by use of social media applications during the lockdown.

Only a couple of days of isolation may cause anxiety and depression to develop. Add to it the imminent possibility of constantly hammering a terrible disease through the media, and you have a prescription for several shades of mental and physical distress.

Impact on Mental health and behavior: Human beings have evolved into social beings, and are designed to live in collaborative communities. Feeling removed from families, friends and employers can be unbalanced and stressful for most people and can lead to psychological and physical health issues in the short or even long term. Psychological consequences of isolation may include a rise in levels of anxiety, aggression, depression, forgetfulness and hallucinations. In those with inherent pre-existing susceptibilities psychiatric disorders that are precipitated and even manifest without precondition in several others. Personal relationships help us cope with tension, and if we lack this outlet for steam, a massive emotional voice will result which, for an average person, is difficult to deal with.

Solitary inmates and patients in segregated medical facilities have also had negative psychological effects including elevated anxiety, panic attacks and elevated paranoia rates. This has been found that social isolation has a correlation with greater alcoholism. Researchers who had to live in remote areas such as deserts, the Antarctica, forests and outer space have confirmed that overcoming loneliness is a tough challenge. Yossi Ghinsberg, an Israeli explorer who spent several weeks alone in the Amazon, admitted making imaginary companions to fend off the loneliness. The shutdown of Covid has put forced isolation on many.

Young people live away from their families, trapped in small apartments with abysmal cooking skills. Many senior citizens living on their own seek companionship by meeting up in community parks with age mates. We find themselves marooned, robbed of social contact and even from their children's sporadic visits. Lack of playtime with peers causes children to become irritable and edgy.

Staying in a confined space with family is not a pink picture for everyone. It may be extremely oppressive and claustrophobic for large low-income families huddled together in small single-room houses. Children are not lucky enough to have a lot of board/electronic games or books to keep them busy. Add to this the profound uncertainty of running out of food funds and basic necessities. On the other hand, there are people with dysfunctional family dynamics, such as dominant, abusive or alcoholic partners, siblings or parents, who make a period of trial stay at home. There has been a worldwide increase in the incidence of suicide and physical abuse against women. Higher anxiety and depression often impair an individual's immune system and make them more vulnerable to disease.

\section{Discussion}

The issue today is not whether the Covid-19 passage will bring similar socio-political changes; experts predict it will be a long and damaging fight. This needs to be preparing for the long term. We need to control our population's physical and psychological harm by urgently diverting full resources to improve our healthcare system. We have to maintain a fair distribution of food and essential needs among the less favoured groups. Before the lockout we tripped badly by misunderstanding their worries. Even more bungling will lead to messy rioting scenarios and food theft. The Government needs to move into action quickly to prevent losing legitimacy. 
A higher death toll also means that many families deprive members of their earnings and put greater burden on the welfare system. Throughout India, losses are the highest in the males of the 22-40 year age group, which is also the most active.

Import and export trade has decreased all over the world due to lack of transport; but environment is seen to be recovering up to great extent.

Today, social media like Twitter, Face book and Instagram have become the main information sources. They are also platforms for misinformation and false news.

\section{Conclusion}

Stigma and blame targeted at outbreak-affected communities may hinder international trade, finance, and relationships, prompting further unrest. Care needs to be taken to erase the stigma associated with disease, racism, religious propaganda and psychosocial impact and to be implemented through regular discussions with trained and specialist healthcare staff by setting up task forces and execution teams that are directly involved in healthcare delivery systems without creating any communication gaps between policy makers and ground level.

It is desperately necessary to set up mental health organizations specific to future pandemics with branches in many nations and individual healthcare institutions for research, delivery of mental healthcare and organization of awareness programs at both personal and community levels. To relieve psychological anxiety in the general population over this continuing pandemic, standardized websites and toll-free helpline numbers can be introduced. Social media should be used in good sense to educate people about dynamics of transmission, disease symptoms, and time when precise medical consultations are required. Strict government laws and legislation regarding fake news, social media rumours, disinformation and misinformation should be implemented to protect social media from devaluations.

The COVID-19 pandemic has clearly shown us how, even in the 21 st century, a "virus" can adversely impact our lives and at the same time make us aware that the greatest assets of humanity are health, goodwill, compassion, unity, creativity and awareness.
Ethical Clearance: Taken from institutional ethics committee.

\section{Source of Funding: Self.}

\section{Conflict of Interest: Nil.}

\section{References}

1. Kondo Nakada L et al. COVID-19 pandemic: Impacts on the air quality during the partial lockdown in São Paulo state, Brazil. Science of the Total Environment. 2020; 730: 139087.

2. Chakraborty $\mathrm{I}$ et al. COVID-19 outbreak: Migration, effects on society, global environment and prevention. Science of the Total Environment. 2020; 728: 138882 .

3. Hassan Shakil $M$ et al. COVID-19 and the environment: A critical review and research agenda. Science of the Total Environment. 2020; 745:141022.

4. Lokhandwala $\mathrm{S}$ et al. Indirect impact of COVID-19 on environment: A brief study in Indian context. 188, 2020, 109807.

5. Akseer $\mathrm{N}$ et al. COVID-19 pandemic and mitigation strategies: implications for maternal and child health and nutrition. The American Journal of Clinical Nutrition, 2020; 112(2): 251-256.

6. Atalan A. Is the lockdown important to prevent the COVID-19 pandemic? Effects on psychology, environment and economy-perspective. Annals of Medicine and Surgery. 2020; 56: 38-42.

7. Jha R et al. Environmental and demographic factor: aspects on covid-19 in Indian population. Journal of critical reviews. 2020; 7(10): 1-3.

8. Muley S etal. COVID 19 in ophthalmology practice: a review article. Journal of critical reviews. 2020; 7(10): 9-11.

9. Jha $\mathrm{R}$ et al. The origin, transmission and mortality of corona virus. Journal of critical reviews. 2020; 7(10): 93-96.

10. Maldure S et al. COVID-19 and otorhinologology: prevention better than cure. Journal of critical reviews. 2020; 7(10): 122-125.

11. Bankar $\mathrm{N}$ et al. COVID-19 review: with special reference to laboratory diagnosis and testing strategy. Journal of critical reviews. 2020; 7(10): 187-192. 